\title{
Influence of papain in biofilm formed by methicillin-resistant Staphylococcus epidermidis and methicillin-resistant Staphylococcus haemolyticus isolates
}

\author{
Hanna Lara da Cruz Dinéas de Oliveira1, Maria Emília Castro Kling Fleming', \\ Patrícia Vollu Silva ${ }^{1}$, Geraldo Renato de Paula ${ }^{1}$, Débora Omena Futuro ${ }^{1}$, Guillermo Coca Velarde ${ }^{2}$, \\ Luciana Maria Ramires Esper ${ }^{1}$, Lenise Arneiro Teixeira ${ }^{1, *}$
}

\author{
${ }^{1}$ Faculty of Pharmacy, Federal Fluminense University, Niterói, RJ, Brazil, ${ }^{2}$ Institute of Mathematics and Statistics, \\ Federal Fluminense University, Niterói, RJ, Brazil
}

\begin{abstract}
Methicillin-resistant Staphylococcus epidermidis (MRSE) and methicillin-resistant Staphylococcus haemolyticus (MRSHa) are important coagulase-negative staphylococci. They are often isolated from bacteremia in humans mainly due to their ability to form biofilm on the surfaces of medical devices. Papain is a complex mixture of proteolytic enzymes and peroxidases extracted from the latex of Carica papaya and it is recognized by accelerating the healing process of wounds. This study aimed to evaluate the ability of the MRSE and MRSHa isolates to produce biofilms. Besides this, the ability of papain to inhibit the formation of biofilms or to disrupt the ones already formed by those bacteria was analyzed. Thirty MRSHa and 30 MRSE were isolated from bacteremia and used in this study. It was observed that papain has ability to reduce biofilms formed by MRSE $(p<0.06)$ and by MRSHa $(p=0.0005)$. In addition, papain was able to disrupt mature biofilms made by MRSE $(p=0.014)$. No antibacterial activity of papain was observed for any isolates of MRSE and MRSHa tested. Papain has been demonstrated as a potential product for reducing biofilm.
\end{abstract}

Uniterms: Staphylococcus epidermidis/methicillin-resistant. Staphylococcus haemolyticus/methicillinresistant. Biofilm/production. Papain/reducing biofilm.

Staphylococcus epidermidis resistente à meticilina (MRSE) e Staphylococcus haemolyticus resistente à meticilina (MRSHa) são importantes estafilococos coagulase negativa. São frequentemente isolados em bacteremia humana, principalmente devido à capacidade de formar biofilmes nas superfícies de dispositivos médicos introduzidos no organismo. A papaína é mistura complexa de enzimas proteolíticas e peroxidases extraídas do látex de Carica papaya, reconhecida por acelerar os processos de cura de feridas. Este estudo teve como objetivo avaliar a capacidade dos MRSE e MRSHa em produzir biofilmes e analisar a capacidade da papaína em inibir a formação de biofilme ou desintegrar biofilmes já formados por essas bactérias. Observou-se que a papaína tem capacidade de reduzir a formação de biofilme por MRSE $(\mathrm{p}<0,06)$ e MRSHa $(\mathrm{p}=0,0005)$. Além disso, a papaína foi capaz de desintegrar biofilme maduro formado por $\operatorname{MRSE}(p=0,014)$. Nenhuma atividade antibacteriana da papaína foi observada para qualquer das duas espécies de bactérias testadas. A papaína mostrou-se produto potencial para reduzir biofilme.

Unitermos: Papaína. Staphylococcus epidermidis/resistente à meticilina. Staphylococcus haemolyticus/ resistente à meticilina. Biofilme/produção. Papaína/redução de biofilme.

\footnotetext{
*Correspondence: L. A. Teixeira. Departamento Tecnologia Farmacêutica,
} Faculdade de Farmácia, Universidade Federal Fluminense. Rua Mário Viana, 523 - Santa Rosa, 24241-002 - Niterói - RJ, Brasil. E-mail: tlenise@hotmail.com 


\section{INTRODUCTION}

Coagulase-negative staphylococci, especially Staphylococcus epidermidis followed by Staphylococcus haemolyticus, have been frequently reported as significant etiological agents that cause nosocomial infections (Keim et al., 2011, Kristóf et al., 2011; Rosado, Romanelli, Camargos, 2011). The most important property of these staphylococci is their capability to form biofilm on the surfaces of foreign bodies introduced into the organism (Donlan, 2011; Sander et al., 2012). The infections are mainly caused by strains that have already colonized parts of the human body, making the colonized person a reservoir that will spread the organisms (Saising et al., 2012).

In biofilms, these organisms are involved in a matrix composed of polysaccharides, proteins, and extracellular DNA, which provides protection against antimicrobial products and immune system (Von Eiff, Heilmann, Peters, 1999; MacCann et al., 2008). The process of biofilm production has not been totally clarified yet, but in S. epidermidis, it seems to occur in two important steps: adherence to the inert surface and biofilm accumulation (Götz, 2002). Many bacterial products are thought to be involved in the initial phase of bacterial adherence, including the Atl and Aap proteins, teichoic acid and staphylococcal adhesins, proteins, which play an important role in the plasma-coated biomaterial. In the second phase, the bacteria attach to the surface of the polymer produce and accumulate an extracellular, amorphous, and mucoid polysaccharide material named biofilm (Von Eiff, Heilmann, Peters, 2002). Studies have indicated that the mature biofilm facilitates colonization and persistence of bacteria in the host (Götz, 2002). In S. epidermidis, the ica operon (encoding enzymes that are involved in biosynthesis of polysaccharide intercellular adhesin; PIA) seems to be essential for the production of biofilm (Araujo et al., 2006).

Papain is a complex mixture of proteolytic enzymes and peroxidases extracted from the papaya latex of Carica papaya. It has been used in Brazil since 1983 to treat wounds (Leite et al., 2012). Several studies have recognized that papain accelerates wound healing processes, especially chronic ones. It can be used in different concentrations according to the type of the wounded tissue (Leite et al., 2012). The treatment of wounds and burns occurs due to papain debriding and anti-inflammatory action (Monetta, 1987; Silva et al., 2007, Chukwuemeka, Anthoni, 2010). Because of antitrypsin $\alpha-1$, an antiprotease that inhibits the action of enzymes in healthy tissues, papain can be safely used in skin without damages (Flindt, 1979). Further, proteolysis in necrotic tissues and cell fragments from a wound aid the healing process (Sanchez Neto et al., 1993;
Leite et al., 2012). In addition, biofilms can also be found in wounds, which makes the treatment more difficult and increases wound bioburden (Kim, Steinberg, 2012; Percival et al., 2012; Dowd, 2008). Moreover, previous experimental and clinical data have recommended using papain to reduce wound bioburden and to promote wound healing (Payne et al., 2008).

Although bactericidal activity of papain has been reported for gram-positive and gram-negative organisms (Dawkins et al., 2003; Chukwuemeka, Anthoni, 2010; Bhardwaj, Ballal, Velmurugan, 2012), there is no consensus about this function. Ferreira et al. (2008) found this activity for Staphylococcus aureus and Pseudomonas aeruginosa only in $10 \%$ of papain. However, Lima et al. (2009) verified that papain has no antibacterial activity for Enterococcus faecalis, P. aeruginosa, S. aureus, Klebsiella pneumoniae, and Salmonella typhi in different concentrations.

Considering the proteolytic characteristic described for papain and the biopolymer matrix composition of bacterial biofilms, this study aimed to evaluate the ability of papain to act as an inhibitor of biofilms in different concentrations. Moreover, given the disagreement of reports analyzed, we also evaluated the antibacterial activity of the papain.

\section{MATERIAL AND METHODS}

\section{Bacterial strains}

To evaluate whether papain had the capacity to interfere in staphylococcal biofilm, 60 hospital isolates (30 methicillin-resistant Staphylococcus epidermidisMRSE and 30 methicillin-resistant Staphylococcus haemolyticus-MRSHa) were analyzed. After that, 78 more isolates (53 MRSE and $25 \mathrm{MRSHa}$ ) were included to determine the minimal inhibitory concentration. The isolates were collected from bloodstream infection and were previously identified as oxacillin resistance. All bacteria were preserved at $-20{ }^{\circ} \mathrm{C}$ at $10 \%$ glycerol stock on Tryptic soy broth (TSB).

\section{Papain solution}

Papain (Prozyn, Brazil) was solubilized in water Milli-Q sterilized to appropriate dilutions and kept in refrigerated for 7 days.

\section{Biofilms assay}

The biofilm formation was induced by TSB supplemented with $1 \%$ glucose $(\mathrm{TSB}+\mathrm{G})$ and was formed on 
inert polystyrene surfaces (96-well microtitre plates, Nuclon; NalgeNunc International, Roskilde, Denmark) as described by Araújo et al. (2006). Staphylococcus epidermidis 70D (strong biofilm producer) and Streptococcus pyogenes ATCC 75194 (biofilm non-producer) were used as positive and negative controls, respectively. The microtitre plates were incubated for $20 \mathrm{~h}$ at $36 \pm 1{ }^{\circ} \mathrm{C}$. The optical density (OD) of the stained biofilm was measured at $560 \mathrm{~nm}$ using a microtitre plate reader. The isolates were classified according to Amaral et al. (2006) as follows: biofilm non-producers $(\mathrm{BU} \leq 0.182)$, weak biofilm producers $(0.182<\mathrm{BU} \leq 0.364)$, moderate biofilm producers $(0.364<\mathrm{BU} \leq 0.728)$, and strong biofilm producers $(\mathrm{BU}>0.728)$.

\section{Effect on bacteria attachment assay}

To determine whether papain directly inhibited attachment of the bacteria to the polystyrene, MRSE and MRSHa isolates were grown for $20 \mathrm{~h}$ in TSB $+\mathrm{G}$ medium in the presence or absence of $2.5 \%$ or $5 \%$ of papain added to well polystyrene microtitre plates (Nuclon; NalgeNunc International, Roskilde, Denmark), followed by staining with crystal violet (Araujo et al., 2006).

\section{Effect on preformed biofilm assay}

We investigated whether papain could affect preformed biofilm produced by $11 \mathrm{MRSE}$ and $11 \mathrm{MRSHa}$. Thus, after biofilm was established, $2.5 \%$ of papain were added to well polystyrene microtitre plates and incubated for 20 hours at $36 \pm 1{ }^{\circ} \mathrm{C}$. After the treatment, the wells were gently washed and stained with violet crystal as described (Araujo et al., 2006).

In all biofilm experiments, each isolate was performed at least twice.

\section{Scanning with inverted microscopy}

Biofilms formatted on the polystyrene microtitre plates were analyzed in 10 isolates (5 MRSE and 5 MRSHa) by scanning microscopy (Nikon Eclipse TE 2000-U model), in order to control the results of the spectrophotometric test. At least five different microscopy fields of each isolate were examined.

\section{Determination of minimal inhibitory concentration (MIC)}

The MIC values were determined by the agar dilution method standardized by the Clinical and Laboratory Standards Institute (CLSI, 2011). Papain was incorporated into the Muller Hinton Agar medium (Difco, Laboratories, USA). Each plate contained different concentrations of papain $(1 \%, 2.5 \%, 5 \%$, and $10 \%$; Prozyn, São Paulo, Brazil). The bacterial suspensions containing approximately $10^{7} \mathrm{CFU} / \mathrm{mL}$ were inoculated onto agar plates using a Steers replicator. The final inoculum on the agar was $10^{4} \mathrm{CFU}$ per spot.

Staphylococcus aureus ATCC 6538P and Staphylococcus epidermidis ATCC 12228 were used as microorganisms control, and drug-free plates were prepared and used as growth controls. After incubation for $24 \mathrm{~h}$ at $37^{\circ} \mathrm{C}$, the lowest concentration of the products able to inhibit bacterial growth was considered the MIC.

\section{Statistical analysis}

The null hypothesis using Student's $t$ test, for a significance level of 0.1 , was performed either for the analyses of the effect of papain on biofilm formation or biofilm disruption.

\section{RESULTS AND DISCUSSION}

\section{Biofilm study}

Biofilms is the most important virulent factor for coagulase-negative staphylococci. Our data showed that $16(53.3 \%)$ of MRSE were able to form biofilm and $17 \%$ of them displayed high ability to form biofilm (Table I). Previous study realized with isolates in the same hospital showed similar results (Araújo et al., 2006). In relation to MRSHa, $21(70 \%)$ isolates were able to produce biofilm, of which $26.6 \%$ of them were classified to be a strong biofilm producer (Table I). Similar to our results, Fredheim et al. (2009) found that $74 \%$ of the $S$. haemolyticus analyzed were able to produce biofilms. However, the biofilm formed by $S$. haemolyticus has not been subject to more detailed studies so far.

TABLE I- Biofilm formation of methicillin-resistant Staphylococcus epidermidis (MRSE) and methicillin-resistant Staphylococcus haemolyticus (MRSHa)

\begin{tabular}{lcc}
\hline \multirow{2}{*}{ Biofilm } & \multicolumn{2}{c}{ Microorganism (\%) } \\
\cline { 2 - 3 } & MRSE & MRSHa \\
\hline Strong & $5(16.6 \%)$ & $8(26.7 \%)$ \\
Moderate & $6(20.1 \%)$ & $5(16.7 \%)$ \\
Weak & $5(16.6 \%)$ & $8(26.7 \%)$ \\
Total producer & $16(53.3 \%)$ & $21(70 \%)$ \\
Non-producer & $14(46.7 \%)$ & $9(30 \%)$ \\
\hline
\end{tabular}


Because staphylococci are among the most likely, microorganisms to contaminate and adhere to any medical device that penetrates host surfaces (Vuong, Otto, 2002), several compounds have been tested as biofilm inhibitors, and some are already used to coat catheters (Huigens et al., 2009; Juda et al., 2008, Maki et al., 1997). Randomized trials have shown the benefits of using antibiotic-impregnated catheters in hospitalized patients to reduce bacterial colonization on the surface of these devices (Maki et al., 1997). In this paper, we explore the effect of different concentrations of papain $(2.5 \%$ or $5 \%$ ) in biofilm production by several MRSE and MRSHa isolates. When papain $(2.5 \%$ or $5 \%)$ was incorporated into the culture, the biofilm formation by MRSE was inhibited $(p=0.06)$. However, the papain action showed to be more effective for MRSHa isolates $(p=0.0005)$. The experiment suggested that papain is able to influence the ability of cells to form biofilm, thus affecting the bacterial attachment. Scanning with inverted microscopy is presented in Figure 1.

It is well known that staphylococcal biofilm formation is multi-factorial and two major enzymes, accumulation-associated protein (Aap) and autolysin

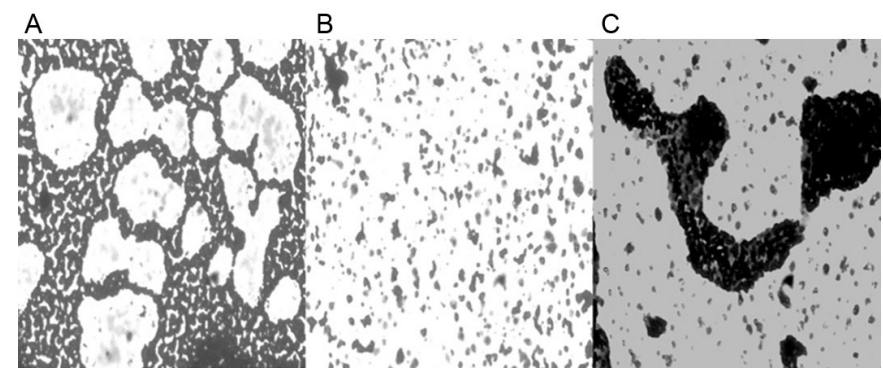

FIGURE 1 - Inverted microscope of biofilm produced by a MRSHa representative isolate on polystyrene surface. (A) Untreated, (B) $5 \%$ papain, and (C) $2.5 \%$ papain. Increased $40 x$.
(Atl), seem to be associated with the first step of biofilm formation (Biswas et al., 2006). In S. epidermidis, PIA production and protein factors (i.e., Aap and AtlE) likely contribute strongly to the development of mature biofilms in vivo in some isolates (Stevens et al. 2009). In their article, it was verified that sodium metaperiodate caused a significant decrease in biofilm formed by PIA and proteinase $\mathrm{K}$ treatment was sufficient to significantly disperse the biofilm matrix, suggesting a role for protein in biofilm production. Autolysins such as AtlE play an important role in cell-wall processing and recycling, and it is interesting to speculate that the major role they have in the process of biofilm formation may be to orientate and expose cell-surface adhesins correctly in order to maximize and ensure an effective interaction with either host factors or device surfaces (Stevens et al., 2009).

Karamanos et al. (1995) reported that the extracellular slime layer of Staphylococcus epidermidis ATCC 35983 contains two non-anionic carbohydrate-containing proteins degradable by papain, and a macromolecule also degradable by papain-bearing acidic carbohydrates covalently bound to protein. Although we did not test the hypothesis in which papain can damage AtlE, it is reasonable to suppose that papain can degrade these biofilm-associated proteins and/or another protein(s) involved in biofilm formation.

On the other hand, to verify whether papain also disrupted the biofilm that accumulated on the polystyrene surface, 22 isolates (11 MRSE and $11 \mathrm{MRSHa}$ ) were used. Thus, preformed biofilms were treated with $2.5 \%$ papain and incubated for 20 hours at $36^{\circ} \mathrm{C} \pm 1{ }^{\circ} \mathrm{C}$. The data obtained for the MRSHa isolates showed no significant influence of the enzyme on biological films ( $p=0.573$ ) (Figure 2A). However, the results showed a huge reduction of the optical densities obtained for MRSE isolates treated with papain compared to the untreated ones (Figure 2B),
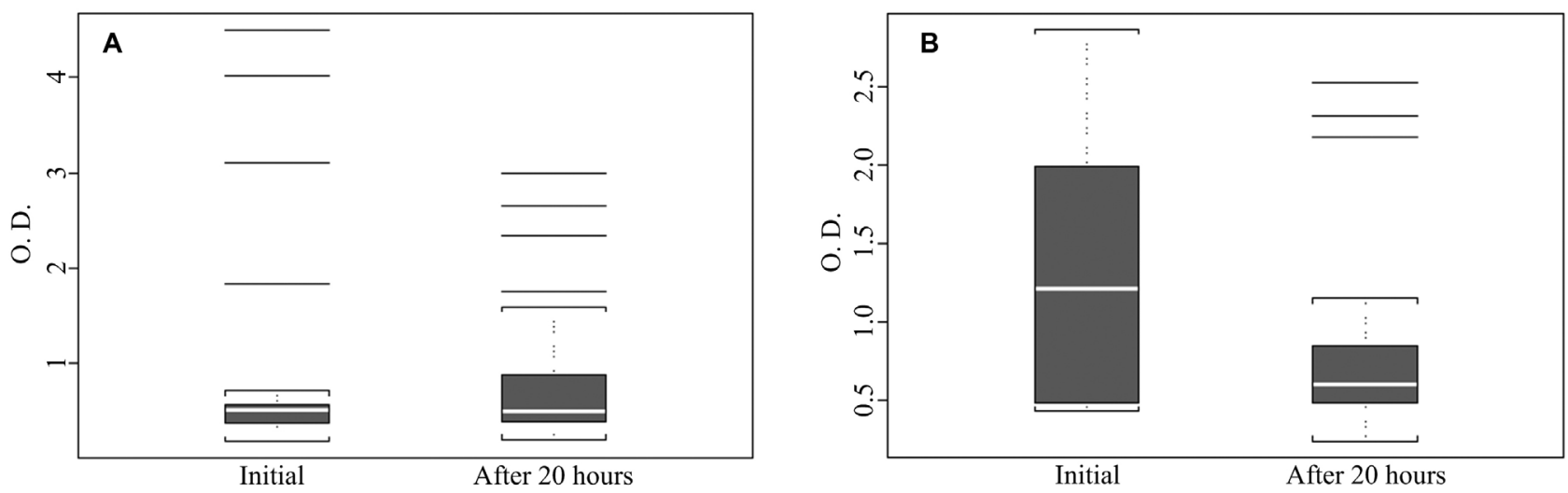

FIGURE 2 - Boxplot of optical densities of biofilms formed by staphylococcal isolates, both untreated and those treated with $2.5 \%$ of papain for a period of 20 hours. (A) Staphylococcus haemolyticus - MRSHa, (B) Staphylococcus epidermis - MRSE. 
with a significance level $p=0.014$. For Orgaz et al. (2011), diverse results against different bacteria may be the consequence of specific features of their biofilm matrix, cell wall or membrane, and/or some intracellular events.

Previous studies have suggested that extracellular proteins seem to be one of the main components of the biofilm matrix formed by S. haemolyticus (Fredheim et al., 2009; Silva et al., 2013). Because of that, we expected papain to disrupt biofilm accumulation produced by MRSHa. In the present study, papain disintegrated better biofilm formed by MRSE, the principal component of which is poly- $\beta-1,6-N$-acetyl-D-glucosamine (PNAG), also known as polysaccharide intercellular adhesin (Götz, 2002). According to Jabbouri and Sadovskaya (2010), the sensitivity of staphylococcal biofilms to enzymatic treatments depends on their chemical composition. The authors report that protein components in biofilms play an important role in stabilizing intercellular structure. Our results demonstrate that more studies are still needed to define the roles and the other components of biofilms formed by staphylococci bacteria.

\section{Determination of minimal inhibitory concentration (MIC)}

Papain is a safe agent to use in wounds with highlevel bacteria because it is able to reduce bioburden (Payne et al., 2008). Thus, we determined the anti-staphylococcal activity of this agent. Six isolates tested showed no susceptibility for $1 \%, 2.5 \%, 5 \%$, or $10 \%$ papain. To confirm this result, we decided to add 78 more isolates; hence, all 138 bacteria analyzed demonstrated no activity to papain at different concentrations.

Several studies reported papain antibacterial activity in gram-positive and gram-negative bacteria (Chukwuemeka, Anthoni, 2010; Bhardwaj, Ballal, Velmurugan, 2012). Nonetheless, Ferreira et al. (2008) verified that only papain gel $10 \%$ was able to inhibit $S$. aureus. Notably, Lima et al. (2009) did not find antibacterial activity of papain for various microorganisms. As shown in our study. Seenivasan et al. (2010) reported that papain has interacted with the bacterial cell membrane, destabilizing it and resulting in osmotic shock and release of cytoplasmic contents, where the antibacterial activity was established. However, in vivo, the association between papain and the reduction of infections observed in the wound seems to be due its anti-inflammatory action, which promotes cellular reproduction, stimulates cytokines production, and recruits phagocytic cells, so that the environment becomes unfavorable for the growth of pathogenic microorganisms (Falanga, 2002; Lima et al., 2009).

\section{CONCLUSION}

Papain seems to be a promising breakthrough in the prevention and disruption of biofilms, a subject of interest of the pharmaceutical industry. Although our experiments showed that papain has no bactericidal activity against Staphylococcus epidermidis and Staphylococcus haemolyticus, it presented a potential product that may reduce biofilm formed by these microorganisms.

\section{ACKNOWLEDGMENTS}

This work was supported, in part, by grants of the Fundação Carlos Chagas de Amparo à Pesquisa do Estado do Rio de Janeiro (FAPERJ, Brazil), Conselho Nacional de Desenvolvimento Científico e Tecnológico (CNPq, Brazil), Coordenação de Aperfeiçoamento de Pessoal de Nível Superior (CAPES, Brazil), Pró-Reitoria de Pesquisa, Pós-graduação e Inovação of the Universidade Federal Fluminense (PROPPi-UFF, Brazil). We thank Professor Dr. Ana Lúcia Marques Ventura from the Neurobiology Department of Biology Institute (UFF) for microscopy experiments and the laboratory technician Wilmar Jorge da Silva for helping us in all experiments.

\section{REFERENCES}

ARAUJO, G.L.; COELHO, L.R.; DE CARVALHO, C.B.; MACIEL, R.M.; CORONADO, A.Z.; ROZENBAUM, R.; FERREIRA-CARVALHO, B.T.; FIGUEIREDO, A.M.; TEIXEIRA, L.A. Commensal isolates of methicillinresistant Staphylococcus epidermidis are also well equipped to produce biofilm on polystyrene surfaces. J. Antimicrob. Chemother., v.57, p.855-864, 2006.

BHARDWAJ, A.; BALLAL, S., VELMURUGAN, N. Comparative evaluation of the antimicrobial activity of natural extracts of morindacitrifolia, papain and aloe vera (all in gel formulation), 2\% chlorhexidine gel and calcium hydroxide, against Enterococcus faecalis: an in vitro study. J. Conserv. Dent., v.15, p.293-297, 2012.

CHUKWUEMEKA, N.O.; ANTHONI, A.B. Antifungal effects of pawpaw seed extracts and papain on post harvest Carica papaya L. fruit rot. Afr. J. Agr. Res., v.5, p.1531-1535, 2010.

CLINICALAND LABORATORY STANDARTS INSTITUTE. CLSI. Methods for dilution antimicrobial susceptibility tests for bacteria that grow aerobically; approved standard. 9.ed. Wayne: CLSI, 2012. 
DAWKINS, G.; HEWITT, H.; WINT, Y.; OBIEFUNA, P.C.; WINT, B. Antibacterial effects of Carica papaya fruit on common wound organisms. West Indian Med. J., v.53, p.290-292, 2003.

DONLAN, R.M. Biofilm elimination on intravascular catheters: important considerations for the infectious disease practitioner. Clin. Infect. Dis., v.52, p.38-45, 2011.

DOWD, S.E.; SUN, Y.; SECOR, P.R.; RHOADS, D.D.; WOLCOTT, B.M.; JAMES, G.A.; WOLCOTT, R.D. Survey of bacterial diversity in chronic wounds using pyrosequencing, DGGE, and full ribosome shot gun sequencing. BMC Microbiol., v.6, p.43, 2008.

FALANGA, V. Wound bed preparation and the role of enzymes: a case for multiple actions of therapeutic agents. Wounds, v.14, p.47-57, 2002.

FERREIRA, A.M.; WATANABE, E.; NASCIMENTO, A.P.; ANDRADE, D.; ITO, I.Y. Atividade antibacteriana in vitro de géis com diferentes concentrações de papaína. Rev. Eletr. Enferm., v.10, p.1035-1040, 2008.

FLINDT, M.L. Allergy to alpha-amylase and papain. Lancet, v.1, p.1407-1408, 1979.

FREDHEIM, E.G.; KLINGENBERG, C.; ROHDE, H.; FRANKENBERGER, S.; GAUSTA, P.; FLAEGSTAD, T.; SOLLID, J.E. Biofilm formation by Staphylococcus haemolyticus. J. Clin. Microbiol., v.47, p.1172-1180, 2009.

GÖTZ, F. Staphylococcus and biofilms. Mol. Microbiol., v.43, p.1367-1378, 2002.

HUIGENS, R.W.; ROGERS III, S.A; STEINHAUER A.T.; MELANDER, C. Inhibition of Acinetobacter baumannii, Staphylococcus aureus and Pseudomonas aeruginosa biofilm formation with a class of TAGE-triazole conjugates. Org. Biomol. Chem., v.7, p.794-802, 2009.

JABBOURI, S.; SADOVSKAYA, I. Characteristics of the biofilm matrix and its role as a possible target for the detection and eradication of Staphylococcus epidermidis associated with medical implant infections. FEMS Immunol. Med. Microbiol., v.59, p.280-291, 2010.
JUDA, M.; PAPROTA, K.; JAŁOZA, D.; MALM, A.; RYBOJAD, P. GOZ'DZIUK, K. EDTA as a potential agent preventing formation of Staphylococcus epidermidis biofilm on polychloride vinyl biomaterials. Ann. Agric. Environ. Med., v.15, p.237-241, 2008.

KARAMANOS, N.K.; PANAGIOTOPOULOU, H.S.; SYROKOU, A.; FRANGIDES, C.; HJERPE, A.; DIMITRACOPOULOS, G.; ANASTASSIOU, E.D. Identity of macromolecules present in the extracellular slime layer of Staphylococcus epidermidis. Biochimie, v.77, p.217-224, 1995.

KEIM, L.S.; TORRES-FILHO, S.R.; SILVA, P.V.; TEIXEIRA, L.A. Prevalence, aetiology and antibiotic resistance profiles of coagulase-negative staphylococci isolated in a teaching hospital. Braz. J. Microbiol., v.42, p.248-255, 2011.

KIM, P.J.; STEINBERG, J.S. Wound care: biofilm and its impact on the latest treatment modalities for ulcerations of the diabetic foot. Semin. Vasc. Surg., v.25, p.70-74, 2012.

KRISTÓF, K.; KOCSIS, E.; SZABÓ, D.; KARDOS, S.; CSER, V.; NAGY, K.; HERMANN, P.; ROZGONYI, F. Significance of methicillin-teicoplanin resistant Staphylococcus haemolyticus in bloodstream infections in patients of the semmelweis university hospitals in Hungary. Eur. J. Clin. Microbiol. Infect. Dis., v.3, p.691-699, 2011.

LEITE, A.P.; OLIVEIRA, B.G.R.D.E.; SOARES, M.F.; BARROCAS, D.L.R. Uso e efetividade da papaína no processo de cicatrização de feridas: uma revisão sistemática. Rev. Gaúcha Enferm., v.33, p.3, 2012.

LIMA, M.B.; MATINS FILHO, E.S.; CARVALHO, R.G.; BRITO JR, L.C. Estudo in vitroda ação bactericida e/ou bacteriostática da papaína. Rev. Para Med., v.23, p.2, 2009.

MAKI, D.G.; STOLZ, S.M.; WHEELER, S.; MERMEL, L.A. Prevention of central venous catheter-related bloodstream infection by use of an antiseptic-impregnated catheter. A randomized controlled trial. Ann. Intern. Med., v.127, p.257-266, 1997.

McCANN, M.T.; GILMORE, B.F.; GORMAN, S.P. Staphylococcus epidermidis device-related infections: pathogenesis and clinical management. J. Pharm. Pharmacol., v.60, p.1551-1571, 2008. 
MONETTA, L. O uso da papaína nos curativos feitos pela enfermagem. Rev. Bras. Enf., v.40, p.66-73, 1987.

ORGAZ, B.; LOBETE, M.M.; PUGA, C.H.; JOSE, C.S. Effectiveness of chitosan against mature biofilms formed by food related bacteria. Int. J. Mol. Sci., v.12, p.817-828, 2011.

PAYNE, W.G.; SALAS, R.E.; KO, F.; NAIDU, D.K.; DONATE, G.; WRIGHT, T.E. Enzymatic debriding agents are safe in wounds with high bacterial bioburdens and stimulate healing. Eplasty., v.7, p.17, 2008.

PERCIVAL, S.L.; HILL, K.E.; WILLIAMS, D.W.; HOOPER, S.J.; THOMAS, D.W.; COSTERTON, J.W. A review of the scientific evidence for biofilms in wounds. Wound Repair Regen.Wound Repair Regen., v.20, p.647-657, 2012.

ROSADO, V.; ROMANELLI, R.M.; CAMARGOS, P.A. Risk factors and preventive measures for catheter-related bloodstream infections. J. Pediatr., v.87, p.469-477, 2011.

SAISING, J.; SINGDAM, S.; ONGSAKUL, M.; VORAVUTHIKUNCHAI, S.P. Lipase, protease, and biofilm as the major virulence factors in staphylococci isolated from acne lesions. Biosci. Trends, v.6, p.160-164, 2012.

SANCHEZ NETO, R.; BARONE, B.; TEVES, D.C.; SIMÕES, M.J.; NOVO, N.F.; JULIANO, Y. Aspectos morfológicos e morfométricos da reparação tecidual de feridas cutâneas de ratos com e sem tratamento com solução de papaína a $2 \%$. Acta Cir. Bras., v.8, p.1823, 1993.

SANDER, G.; BÖRNER, T.; KRIEGESKORTE, A.; VON EIFF, C.; BECKER, K.; MAHABIR, E. Catheter colonization and abscess formation due to Staphylococcus epidermidis with normal and small-colony-variant phenotype is mouse strain dependent. PLoS One, v.7, 2012.
SEENIVASAN, R.; ROOPA, L.; GEETHA, S. Investigations on purification, characterization and antimicrobial activity of enzyme papain from Carica papaya Linn. J. Pharm. Res., v.3, p.1092, 2010.

SILVA, J.A.T.; ZINIA, R.; DUONG, T.N.; DHARINI, S. Papaya (Carica papaya L.) biology and biotechnology. Tree For. Sci. Biotech., v.1, p.47-73, 2007.

SILVA, P.V.; CRUZ, R.S.; KEIM, L.S.; PAULA, G.R.; CARVALHO, B.T.; COELHO, L.R.; CARVALHO, M.C.; ROSA, J.M.; FIGUEIREDO, A.M.; TEIXEIRA, L.A. The antimicrobial susceptibility, biofilm formation and genotypic profiles of Staphylococcus haemolyticus from bloodstream infections. Mem. Inst. Oswaldo Cruz, v.108, p.812-816, 2013.

STEVENS, N.T.; GREENE, C.M.; O'GARA, J.P.; HUMPHREYS, H. Biofilm characteristics of Staphylococcus epidermidis isolates associated with devicerelated meningitis. J. Med. Microbiol., v.58, p.855-862, 2009.

VON EIFF, C.; HEILMANN, C.; PETERS, G. New aspects in the molecular basis of polymer-associated infections due to staphylococci. Eur. J. Clin. Microbiol. Infect. Dis., v.18, p.843-846, 1999.

VUONG, C.; OTTO, M. Staphylococcus epidermidis infections. Microbes Infect., v.4, p.481-489, 2002.

Received for publication on $23^{\text {th }}$ March 2013 Accepted for publication on $07^{\text {th }}$ August 2013 
